J. Product. \& Dev., 22(1): 11-28 (2017)

\title{
GROWTH PERFORMANCE, CARCASS TRAITS AND BLOOD CONSTITUENTS OF WEANED NEW ZEALAND WHITE RABBITS AS AFFECTED BY INCLUSION DIETARY Moringa oleifera LEAF MEAL (MOLM) IN THEIR RATION.
}

\author{
A. A .Gomaa; A. A. Rashwan and M. I. Tewfik
}

Animal \& Poultry Production Department, Faculty of Technology and Development, Zagazig University, Zagazig, Egypt

\section{ABSTRACT:}

The present study was conducted to investigate the effect of replacement $20 \%$ of the total amount of the soybean meal (SBM) in the ration (equal 3.6\%) with (5.2\%) Moringa oleifera leaf meal, (MOLM) on growth performance, carcass traits, meat quality and blood constituents of growing New Zealand White (NZW) rabbits from 5 to 12weeks of age. A total 40 growing NZW rabbits 5 weeks aged and a body weight of $565 \pm 5 \mathrm{~g}$ and was divided to two experimental groups $(20$ rabbits in each group has been deployed to five replicates by 4 rabbits in each). The first group, fed the basal ration (zero\% MOLM) a served as control, the second group fed diet contained 5.2\% MOLM (replaced instead of 3.2\% SBM, which represent $20 \%$ of the used total amount of SBM in the ration). Ration was iso - caloric and protein.

Results were discussed and the most important results have summarized as follows: there is no differences in the final weight and weight gain of the rabbits at $12^{\text {th }}$ week of age. The Results of carcass traits showed absence of significant differences in the weight of each of the blood, fur, kidneys, liver, heart, head, and the spleen between the two experimental groups. Also no significant differences were recorded for the meat components (moisture, protein, fat, fiber and carbohydrates) between the two groups. As well as there were no significant differences in the assessment of blood constituents, whether for rabbits fed moringa or control group in each of total protein, albumin, globulin, GPT, GOT, creatinine, uric acid, glucose, hemoglobin, red blood cells, white blood cells, blood platelets. No Specific direction was observed to distinguish any of the two groups, The obtained results showed that the highest economic efficiency was (88.28\%) for the second group which fed diet contained $3.2 \%$ MOLM, while, the first group (control) was (81.47\%) respectively. 
Conclusively, it can be concluded that, Moringa Leaf Meal (MLM) can be used safely in feeding NZW rabbits to alternate a part of rabbit food (Soybean meal) with untraditional food in Egypt such as (Moringa oleifera Leaf Meal) without any adverse effect on the growing, slaughter test, meat quality and blood characteristics.

Keywords: Growth performance, Carcass traits, blood constituents, economical efficiency, Moringa oleifera, soybean meal, growing Rabbits.

\section{INTRODUCTION:}

In developing countries such as Egypt, efforts have been made towards solving feeds shortage by investigating more unconventional feeds for availability in animal feed, Soya bean meal have been widely and successfully used as conventional protein sources for livestock (Sarwatt et al., 2002). The recommended policy is to identify and use locally available feed resources to formulate diets that are as balanced as possible (Guèye and Branckaert, 2002). There is the need, therefore, to explore the use of non-untraditional feed sources that have the capacity to yield the same output as conventional feeds, and perhaps at cheaper cost.

Hence, any similar high protein ingredient, which could partially or completely be used as a substitute for soybean meal is desirable. Moringa oleifera is in the group of high-yielding nutritious browse plants with every part having food value (Duke, 1998). Leaves of the moringa tree are the preferred part for use in animal diets as leaf meal. Researchers were conducted to study the effect of this leaf meal on the growth performance traits, carcass, and blood indices of weaned rabbits (Nuhu, 2010; Odetola et al, 2012 and said El-Sheikh et al., 2014).Studies on $M$. oleifera showed that the leaves are rich in energy and vitamins (Ayssiwede et al., 2011 and Mutayoba et al., 2011) and has low anti-nutritional factors. Despite the high crude protein content of moringa leaf meal, there is little information available on the use of this unconventional feed resource, especially as an alternative protein supplement for rabbit production.

Therefore, the present study was conducted to investigate the effect of replacement $20 \%$ of the total amount of the soybean meal in the ration (equal $3.6 \%$ ) with moringa oleifera leaf meal (5.2\%) on growing, carcass, meat composition and blood constituents of growing New Zealand White (NZW) rabbits. 


\section{MATERIALS AND METHODS}

The present study was carried out in a farm located at Dakahlia Governorate, East of the Delta, Egypt, during the period from November 2015 to January 2016). An experimental plot of moringa plants was established data Farm belonging to the Faculty of Technology and Development, Zagazig University, Zagazig, Egypt and located in (Ghazala El-Khies, Abu- Alaakhdar, Zagazig, Sharkya Governorate). Feed diets were prepared at Atmida Factory for Animal Food, Daqahlya Governorate, Egypt. The analysis of Moringa oleifera leaf meal (MOLM) and basal diets were conducted in (Central Laboratory and chemical analysis of blood samples, were conducted in Laboratory of Department belonging to Elsheruk Laboratory (Zagazig), and the analysis of Meat quality, were conducted in Laboratory of Department belonging to Department of Food and Dairy Science College Lab., Faculty of Technology and Development, Zagazig University, Zagazig.

\section{Animals and feed formulation:}

This study was conducted on 40 New Zealand White (NZW) weaned, 5 weeks aged and a body weight averaged $565 \pm 5 \mathrm{~g}$. Animals were randomly divided into two experimental groups with 5 replicates / 4 rabbits per each cage. The first treatment group was served as control group (C) and the rabbits fed the basal diet without experimental Moringa oleifera leaf meal (MOLM) addition. The rabbits of the second treatment group $\left(\mathrm{T}_{2}\right)$ were provided with diet in which $3.2 \%$ of soybean meal (SBM) was substituent with $(5.2 \%)$ (MOLM). The diets for the two experimental groups were adjusted to be isoprotein and isocalorie (Table 1a). Components and chemical composition of the experimental rations were formulated according to NRC (1977). Chemical analysis of Moringa powder leaves and soybean meal according to AOAC (1994) as shown in Table 1b.

The experimental animals were housed in galvanized wire cages batteries (60 X 55 X 40cm), in a well-ventilated building (natural through the window).Feed was provided ad libitum. Fresh water was available all the time from automatic drinkers with nipples for each cage. All rabbits in each treatment group were kept under the same managerial, hygienic and environmental conditions, during the experimental period. The experiment lasted for 56 days and all rabbits subjected to the same environmental conditions of temperature, humidity and ventilation. 
Table 1a: Components of the experimental rations

\begin{tabular}{|c|c|c|}
\hline Ingredients & $\begin{array}{c}\text { T1 } \\
(\text { 0.0 MOLM) } \\
\text { Control, \% } \\
\end{array}$ & $\begin{array}{c}\text { T2 } \\
\text { SBM substitute with } \\
(5.2 \%)(\text { MOLM), \% }\end{array}$ \\
\hline Yellow corn & 17.0 & 17.0 \\
\hline Barley & 18.0 & 18.0 \\
\hline Wheat bran & 25.5 & 25.5 \\
\hline Soybean meal & 16.0 & 12.8 \\
\hline Alfalfa hay & 20.5 & 18.5 \\
\hline Moringa leaves & 0.0 & 5.2 \\
\hline Limestone powder & 2.0 & 2.0 \\
\hline Salt & 0.5 & 0.5 \\
\hline Premix growth* & 0.3 & 0.3 \\
\hline Methionine & 0.1 & 0.1 \\
\hline Anti Mycotoxins & 0.1 & 0.1 \\
\hline Total & 100 & 100 \\
\hline \multicolumn{3}{|c|}{ Chemical composition, \% (on DM basis) Calculated: $* * *$} \\
\hline $\mathrm{OM}, \%$ & 85.12 & 85.12 \\
\hline $\mathrm{CP}, \%$ & 17.68 & 17.68 \\
\hline $\mathrm{CF}, \%$ & 10.71 & 10.71 \\
\hline EE, \% & 12.0 & 12.0 \\
\hline Ash, \% & 14.88 & 14.88 \\
\hline NFE, \% & 38.25 & 38.25 \\
\hline $\mathrm{DE}(\mathrm{kcal} / \mathrm{kg}) * *$ & 2300 & 2300 \\
\hline Calcium, \% & 1.1 & 1.1 \\
\hline Tot. Phosphorus, \% & 0.53 & 0.53 \\
\hline Avail. Phosphorus, \% & 0.50 & 0.50 \\
\hline Lysine, $\%$ & 0.87 & 0.87 \\
\hline Met + Cys, \% & 0.62 & 0.62 \\
\hline Feed cost per kg gain & 13.77 & 13.27 \\
\hline
\end{tabular}

* Each per 1 kg diet: 6000 IU Vit. A; 900 IU, Vit. $\mathrm{D}_{3} ; 40 \mathrm{mg}$, Vit.E; $2.0 \mathrm{mg}$, Vit. $\mathrm{K}_{3} ; 2.0$ mg Vit. $B_{1} ; 4.0 \mathrm{mg}$, Vit $B_{2} ; 2.0 \mathrm{mg}$, Vit. $B_{6} ; 0.010 \mathrm{mg}$, Vit. $B_{12} ; 5.0 \mathrm{mg}$ Vit. PP; 10.0 $\mathrm{mg}$ Vit., $\mathrm{B}_{5} ; 0.05 \mathrm{mg}, \mathrm{B}_{8} ; 3.0 \mathrm{mg}, \mathrm{B}_{9} ; 250 \mathrm{mg}$, Choline; $50.0 \mathrm{mg}$, Fe;50.0 mg, Zn; 8.5 $\mathrm{mg} \mathrm{Mn} ; 5.0 \mathrm{mg} \mathrm{Cu} ; 0.20 \mathrm{mg} \mathrm{I}$, and $0.01 \mathrm{mg} \mathrm{Se}$.

** DE $(\mathbf{k c a l} / \mathbf{g})=4.36-0.0491 \mathrm{x} \mathrm{NDF}$, Where NDF \%=28.924+0.657xCF\%, according to Cheeke, (1987).

*** Calculated according to NRC (1977) for rabbits 
Table 1b: Chemical analysis of Moringa powder leaves and soybean meal, according to AOAC (1994).

\begin{tabular}{|l|c|c|}
\hline \multicolumn{1}{|c|}{ Items } & $\begin{array}{c}\text { Moringa powder } \\
\text { leaves }\end{array}$ & $\begin{array}{c}\text { Soybean } \\
\text { Meal }\end{array}$ \\
\hline \multicolumn{2}{|c|}{ Chemical analysis (Determined, \%): } \\
\hline Crude protein(CP), \% & 27.10 & 44.00 \\
\hline Ether extract (EE), \% & 2.30 & 21.00 \\
\hline Crude fiber (CF), \% & 19.20 & 4.9 .0 \\
\hline Ash, \% & 11.22 & 7.93 \\
\hline
\end{tabular}

\section{Data Collection:}

Initial body weight of the rabbit was taken before assigning them to the various treatments. Then body weight was weighed weekly. The average of body weight gain was calculated by determining the difference between two successive weights on weekly basis. The experimental diets were offered daily ad libitum. The daily supply was about 5\% of the body weight of the rabbit. While, the feed wastage was weighed daily before feeding. Total amount of consumed feed weekly were calculated for each of the experimental groups as follows:

Total feed consumed weekly $=$ Total offered feed per week - Total wastage feed per week.

Feed conversion was calculated during a certain period as follows:

$\mathrm{FCR}=$ Feed consumed $(\mathrm{g}) \backslash$ Weight gain $(\mathrm{g})$.

\section{Carcass traits evaluation:}

At the end of the feeding experiment at $12^{\text {th }}$ week of age, 9 rabbits $(3$ rabbits for each group) were randomly selected, starved offeed for 12 hours and weighed, then manually slaughtered by cutting the jugularveim into all owproper bleeding. Edible offals (liver, heart, spleen and kidneys) and nonedible offals were separately weighed and recorded according to Blasco et al., (1993).

\section{Meat composition:}

The meat composition of the carcasses was determined by taking meat samples from the shoulder, chest and thighs of the three rabbits of each group and was placed together in their own envelope (separately for each part of the 
rabbits). Collected samples of the rabbit's meat assigned for chemical analysis to determine the percentage of moisture, crude protein, crude fat and crude ash using the procedures outlined by AOAC (1994).

\section{Blood sample collection and analysis:}

Blood samples were individually collected at $13^{\text {th }}$ week of age from 6 rabbits ( 3 rabbits for each group) just immediately from slaughtered rabbits in a heparinized centrifuge tubes. Total protein, albumin, globulin, GlutamicOxaloacetic Transaminase (GOT), Glutamic-Pyrovic Transaminase (GPT), sugar, red blood cells, white blood cells, platelets, creatinine, hemoglobin and uric acid). Albumin concentration (Al) was determined by the Bromocresol Green (BCG) method (Peters et al., 1982). Globulin (GB) concentration was computed as the difference between total protein and albumin concentrations. Glutamic- Oxaloacetic Transaminase (GOT), Glutamic- Pyrovic Transaminase (GPT) were determined by the method illustrated by Reitman and Frankel (1957), The red blood cell (RBC) counts, total white blood cell (WBC) counts and haemoglobin $(\mathrm{Hb})$ concentration were determined following standard procedures described by Davice and Lewis (1991).

\section{Statistical analysis:}

The experimental treatment groups were assigned the two experimental diets in a Completely Randomized Design (CRD). Each treatment group was replicated five times and there were four rabbits per replicate. Data were subjected to analysis of variance and Statistical analysis was carried out according to Snedecor and Cochran (1984) one way analysis of variance was carried out using the following model:

$$
\mathrm{Y}_{\mathrm{ij}}=\mu+\mathrm{T}_{\mathrm{i}}+\mathrm{e}_{\mathrm{ij}}
$$

Where, $Y_{i j}=$ An observation, $\mu=$ Overall mean, $T_{i}=$ Effect of treatment groups, $\mathrm{I}=(1$ and 2$)$ for feeding moringa diets, $\mathrm{E}_{\mathrm{ij}}=$ Random error

All the data collected were subjected to analysis of variance using ANOVA (SPSS, 2004). Data estimated in percentage form were subjected to arc-sin transformation values (Warren and Gregory, 2005) to approximate normal distribution before being analysed and were re-transformed again to the original scale before presentation. Significant differences between treatments means were determined using Duncan's multiple-range test (Duncan, 1955). Mortality rate was calculated using Chi square.

The significant differences among treatments means were measured by Duncan's New Multiple Range-Test (Duncan, 1955). 


\section{RESULTS AND DISCUSSION:}

\section{Effect of inclusion dietary Moringa Leaf Meal (MOLM) in rabbit's ration on:}

\subsection{Growth performance:}

Results of growth performance of NZW growing rabbits as affected by inclusion dietary Moringa Leaf Meal (MOLM) in their ration is presented in Tables (2, 3, and4). The results presented in Tables $2 \& 3$ showed that NZW rabbit's body weight at the end of the experimental period (week $12^{\text {th }}$ ) as well as, the total \& daily weight gain (5-12 weeks of age) slightly increased with using ration contain moringa leave meal (MOLM) as compared with the control group, however these differences were not statistically significant $(\mathrm{P} \leq$ 0.05). Moringa supplementation might play a role as growth enhancer for rabbits and in case of substituent with soybean it may be due to protein quality and amino acids content of moringa leaves. The obtained results in the present study agreed with those obtained by Nuhu (2010) and Odetola et al. (2012) when fed graded levels of dried Moringa oleifera leaf meal (MOLM) of 0\%, $5 \%, 10 \%$, and $15 \%$, as a replacement of soya bean meal (SBM) found that the mean values obtained for final weight and total weight gain were not significantly $(\mathrm{P}>0.05)$ influenced by the dietary treatments. In contrast, the results of the present study disagreed with those results of (Kpodekon et al., 2009, Aboh et al. 2012; Adeniji and Lawal ,2012; Dougnon et al.,2012, A.Y.El -Badawi et al. ,2014; Ibrahim et al. ,2014;Said ,2014 and Ufele, et al. ,2013) who found significant increase $(P \leq 0.05)$ in the final body weight, total and daily body weight gain when fed growing rabbits on diet containing different levels of Moringa seeds or Moringa leaf meal.

Results presented in Table (3) showed nearly corresponding feed consumption and feed conversion (by the end of experimental period) between the control (0.0 moringa) and treatment (inclusion 5.2\% moringa leaf meal in its ration) groups. These results agreed with the results of Nuhu (2010), Said (2014) either for feed consumption or feed conversion and with the results of Ewuola et al. (2012) regarding feed intake. However, the results of the present study disagree with those results of Oyedele (2008), Adeniji et al. (2010), Dougnon et al. (2012), Ibrahim et al. (2014) and Safwat et al., (2014) who found better significantly $(\mathrm{P} \leq 0.05)$ feed conversion with rabbits fed moringa as feed additive or replacing soybean meal when compared with rabbits did not fed moringa. 
Table 2: Body weight for weaned NZW rabbits as affected by inclusion dietary moringa leaf meal in their ration (Means $\pm \mathrm{SE}$ ).

\begin{tabular}{|c|c|c|}
\hline \multirow{2}{*}{$\begin{array}{c}\text { Age } \\
\text { Weeks) }\end{array}$} & \multicolumn{2}{|c|}{ Experimental rations } \\
\cline { 2 - 3 } & $\begin{array}{c}\mathbf{T}_{\mathbf{1}} \\
(\mathbf{0 . 0} \text { MOLM) } \\
\text { Control }\end{array}$ & $\begin{array}{c}\mathbf{T}_{\mathbf{2}} \\
\text { SBM substitute with } \\
(\mathbf{5 . 2 \%}) \text { (MOLM). }\end{array}$ \\
\hline $\mathbf{W}_{\mathbf{5}}$ & $560.75 \pm 21.30$ & $570.00 \pm 22.06$ \\
\hline $\mathbf{W}_{\mathbf{8}}$ & $900.52 \pm 41.55$ & $947.00 \pm 43.89$ \\
\hline $\mathbf{W}_{\mathbf{1 3}}$ & $1687.63 \pm 51.81$ & $1706.25 \pm 77.61$ \\
\hline
\end{tabular}

Differences between the experimental groups were not statistically significant $(\mathrm{P} \leq$ $0.05)$.

Table 3: Body weight gain (g), feed consumption and feed conversion for weaned NZW rabbits as affected by inclusion dietary moringa leaf meal in their ration (Means \pm SE of total (t) \& daily (d)).

\begin{tabular}{|c|c|c|c|c|c|c|c|}
\hline \multirow{2}{*}{\multicolumn{2}{|c|}{$\begin{array}{c}\text { Periods } \\
\text { (Weeks, wk) }\end{array}$}} & \multicolumn{2}{|c|}{ Body weight gain (g) } & \multicolumn{2}{|c|}{ Feed Consumption } & \multicolumn{2}{|c|}{ Feed Conversion } \\
\hline & & $\begin{array}{c}\mathrm{T}_{1} \\
(\mathbf{0 . 0} \\
\text { MOLM) } \\
\text { Control }\end{array}$ & $\begin{array}{c}\mathbf{T}_{2} \\
\text { SBM } \\
\text { substitute } \\
\text { with (5.2\%) } \\
\text { (MOLM). }\end{array}$ & $\begin{array}{c}\mathrm{T}_{1} \\
(\mathbf{0 . 0} \\
\text { MOLM) } \\
\text { Control }\end{array}$ & $\begin{array}{c}\mathbf{T}_{2} \\
\text { SBM } \\
\text { substitute } \\
\text { with (5.2\%) } \\
\text { (MOLM). }\end{array}$ & \begin{tabular}{c|}
$\mathrm{T}_{1}$ \\
$(\mathbf{0 . 0}$ \\
MOLM) \\
Control
\end{tabular} & $\begin{array}{c}\mathbf{T}_{2} \\
\text { SBM } \\
\text { substitute } \\
\text { with (5.2\%) } \\
\text { (MOLM). }\end{array}$ \\
\hline \multirow[t]{2}{*}{$\left(w k_{5}-w k_{8}\right)$} & $\mathrm{t}$ & $\begin{array}{l}339.77 \\
\pm 20.25\end{array}$ & $\begin{array}{r}377.00 \\
\pm 30.94\end{array}$ & $\begin{array}{c}1586.97 \\
\pm 1.90\end{array}$ & $\begin{array}{c}1628.25 \\
\pm 1.65\end{array}$ & $\begin{array}{c}4.68 \\
\pm 1.68\end{array}$ & $\begin{array}{c}4.31 \\
\pm 0.68\end{array}$ \\
\hline & d & $\begin{array}{r}16.63 \\
\pm 1.47\end{array}$ & $\begin{array}{l}17.66 \\
\pm .74\end{array}$ & $\begin{array}{l}75.57 \\
\pm 0.09\end{array}$ & $\begin{array}{l}77.53 \\
\pm 0.07\end{array}$ & $\begin{array}{c}4.68 \\
\pm 1.68\end{array}$ & $\begin{array}{c}4.31 \\
\pm 0.68\end{array}$ \\
\hline \multirow[t]{2}{*}{$\left(w_{k_{8}}-w k_{13}\right)$} & $\mathrm{t}$ & $\begin{array}{l}787.10 \\
\pm 21.42\end{array}$ & $\begin{array}{r}759.25 \\
\pm 43.48\end{array}$ & $\begin{array}{c}3657.36 \\
\pm 6.00\end{array}$ & $\begin{array}{c}3610.25 \\
\pm 2.46\end{array}$ & $\begin{array}{c}4.65 \\
\pm 0.13\end{array}$ & $\begin{array}{c}4.76 \\
\pm 0.27\end{array}$ \\
\hline & $\mathrm{d}$ & $\begin{array}{c}22.48 \\
\pm .61\end{array}$ & $\begin{array}{l}21.66 \\
\pm 1.20\end{array}$ & $\begin{array}{r}104.49 \\
\pm 0.17\end{array}$ & $\begin{array}{l}103.15 \\
\pm 0.07\end{array}$ & $\begin{array}{c}4.65 \\
\pm 0.13\end{array}$ & $\begin{array}{c}4.76 \\
\pm 0.27\end{array}$ \\
\hline \multirow[t]{2}{*}{$\left(w_{k_{5}}-w k_{13}\right)$} & $\mathrm{t}$ & $\begin{array}{c}1126.86 \\
\pm 41.51 \\
\end{array}$ & $\begin{array}{l}1136.25 \\
\pm 69.39 \\
\end{array}$ & $\begin{array}{c}5244.33 \\
\pm 5.29 \\
\end{array}$ & $\begin{array}{c}5238.50 \\
\pm 2.84 \\
\end{array}$ & $\begin{array}{c}4.66 \\
\pm 0.20 \\
\end{array}$ & $\begin{array}{c}4.61 \\
\pm 0.32 \\
\end{array}$ \\
\hline & $\bar{d}$ & $\begin{array}{l}20.11 \\
\pm .74\end{array}$ & $\begin{array}{r}20.29 \\
\pm 1.23 \\
\end{array}$ & $\begin{array}{c}93.64 \pm \\
0.09\end{array}$ & $\begin{array}{l}93.54 \\
\pm 0.05\end{array}$ & $\begin{array}{c}4.66 \\
\pm 0.20\end{array}$ & $\begin{array}{c}4.61 \\
\pm 0.32\end{array}$ \\
\hline
\end{tabular}

Differences between the experimental groups within each trait were not statistically significant $(\mathrm{P} \leq 0.05)$.

Results presented in Table (4) showed that the control had 5\% mortality as compared with $2.5 \%$ for the treated group $\mathrm{T}$ (3.2\% soybean substituent with 5.2\% MOLM). These results refer that using moringa leaf meal in rabbit diet substitute with soybean meal has no effect on mortality 
rate of the experimental rabbits. Nuhu (2010) also found that increasing level of MOLM up to $20 \%$ in rabbit's feed, did not affect mortality rate for the experimental rabbits.

Table 4: Means of mortality rate (\%) for weaned NZW rabbits as affected by inclusion dietary moringa leaf meal in their ration.

\begin{tabular}{|l|c|c|}
\hline \multirow{2}{*}{ Periods } & \multicolumn{2}{|c|}{ Mortality rate (\%) } \\
\cline { 2 - 3 } & $\begin{array}{c}\mathbf{T}_{1} \\
(\mathbf{0 . 0} \text { MOLM) } \\
\text { Control }\end{array}$ & $\begin{array}{c}\mathbf{T}_{2} \\
\text { SBM substitute with (5.2\%) } \\
\text { (MOLM). }\end{array}$ \\
\hline$\left(\mathbf{w k}_{\mathbf{5}}-\mathbf{w k}_{\mathbf{8}}\right)$ & 0.0 & 0.0 \\
\hline$\left(\mathbf{w k}_{\mathbf{8}}-\mathbf{w k}_{13}\right)$ & 5.0 & 2.5 \\
\hline$\left(\mathbf{w k}_{\mathbf{8}}-\mathbf{w k}_{13}\right)$ & 5.0 & 2.5 \\
\hline
\end{tabular}

Differences between the experimental groups were not statistically significant $(\mathrm{P} \leq 0.05)$.

Results presented in Table (5) showed that all studied carcass traits (weights of each of fur, giblets (kidneys, liver, heart), head, hot carcass and dressed per pre slaughter weight) were not statistically significant $(\mathrm{P} \leq 0.05)$ by substituent $3.2 \%$ soybean meal with $5.2 \%$ MOLM in T group as compared with the control group. These results refer that there were no adverse effect with using moringa leaf meal in rabbit's diet on carcass traits. Same results were obtained previously by (Dougnon et al. (2012) 2012) with carcass yield and offal. In contrast, Odetola et al. (2012) found that weight of carcass, spleen, lungs and heart were significantly $(\mathrm{P} \leq 0.05)$ higher with Moringa oleifera leaf meal (MOLM) $5 \%, 10 \%$, and $15 \%$, as a replacement of soya bean meal in the growing rabbits diet than that of the control group $(0.0 \%$ MOLM). Different trends were recorded by A.Y.El -Badawi et al. (2014), while they found that carcass was significantly $(\mathrm{P} \leq 0.05)$ higher for rabbits fed 0.15 and $0.30 \%$ moringa leaf meal supplemented rations than control, they found that supplementation with $0.45 \%$ had adverse effect on carcass traits. On the other hand, Said (2014) found that using moringa (1 or 3\%) in growing rabbit's feed gained higher significantly $(P \leq 0.05)$ carcass weight 
Table 5: Carcass traits of NZW rabbits as affected by inclusion dietary moringa leaf meal in their ration (Means $(\mathrm{g}) \pm \mathrm{SE})$.

\begin{tabular}{|c|c|c|}
\hline \multirow{2}{*}{ Traits } & \multicolumn{2}{|c|}{ Carcass traits } \\
\cline { 2 - 3 } & $\begin{array}{c}\mathbf{T}_{\mathbf{1}} \\
\text { (0.0 MOLM) } \\
\text { Control }\end{array}$ & $\begin{array}{c}\mathbf{T}_{\mathbf{2}} \\
\text { SBM substitute with (5.2\%) } \\
\text { (MOLM). }\end{array}$ \\
\hline Pre slaughter live body wt., g & $1668.33 \pm 54.18$ & $1781.66 \pm 59.18$ \\
\hline Blood wt., g & $49.33 \pm 1.66$ & $58.33 \pm 8.33$ \\
\% & $2.59 \pm 01$ & $2.96 \pm 35$ \\
\hline Fur wt., g & $300.66 \pm 13.64$ & $334.34 \pm 15.27$ \\
\% & $15.66 \pm 34$ & $16.25 \pm .34$ \\
\hline Head wt., g & $143.33 \pm 8.81$ & $158.33 \pm 10.13$ \\
\% & $7.98 \pm .37$ & $8.31 \pm 39$ \\
\hline Non-Giblets wt., g & $161.66 \pm 9.67$ & $187.34 \pm 12.55$ \\
\% & $9.65 \pm .47$ & $10.48 \pm .39$ \\
\hline Giblets wt.:, g & $65.00 \pm 5.00$ & $71.66 \pm 6.00$ \\
\% & $3.89 \pm 25$ & $4.01 \pm 27$ \\
\hline Kidneys wt., g & $18.33 \pm 3.33$ & $20.00 \pm 2.88$ \\
\% & $1.09 \pm .18$ & $1.12 \pm .17$ \\
\hline Liver wt., g & $41.66 \pm 1.66$ & $46.66 \pm 4.40$ \\
\% & $2.49 \pm 09$ & $2.60 \pm 16$ \\
\hline Heart wt., g & $5.00 \pm .00$ & $5.00 \pm .00$ \\
\% & $.29 \pm .01$ & $.27 \pm .00$ \\
\hline Carcass wt.**, g & $948.35 \pm 33.29$ & $971.66 \pm 17.55$ \\
\% & $55.68 \pm 79$ & $54.46 \pm 1.44$ \\
\hline Dressed wt.*, g & $1317.33 \pm 39.40$ & $1388.66 \pm 22.91$ \\
\% & $67.55 \pm .24$ & $66.79 \pm .94$ \\
\hline
\end{tabular}

N.S: Not Significant $(\mathrm{P} \leq 0.05)$.

Dressed wt. $* \%=$ Hot carcass wt + giblets wt., g / Pre slaughter live body wt., g x100 $\mathrm{SE}=$ Standard error

than control group, however the other organs of carcass traits apart of abdominal fat were not significant nificant $(\mathrm{P} \leq 0.05)$ affected by MPLM supplementation.

Results presented in Table (6) showed that no differences were noted in the meat samples concerning the all studied traits (Protein, fat, moister content, carbohydrates and ash) of rabbit's meat composition in the present study. These results refer that using moringa leaf meal in rabbit diet substitute with a part of soybean meal has no adverse effect on chemical composition of the rabbit meat. Meanwhile, the values of the components of the rabbit's meat for the two 
Table (6): NZW rabbit's meat composition as affected by inclusion dietary moringa leaf meal in their ration (Means $\pm \mathrm{SE}$ ).

\begin{tabular}{|c|c|c|c|}
\hline $\begin{array}{c}\text { Traits } \\
(\%)\end{array}$ & $\begin{array}{c}\text { Rabbit's } \\
\text { meat from }\end{array}$ & $\begin{array}{c}\mathrm{T}_{1} \\
(0.0 \text { MOLM) } \\
\text { Control }\end{array}$ & $\begin{array}{c}\mathrm{T}_{2} \\
\text { SBM substitute with } \\
(5.2 \%) \text { (MOLM). }\end{array}$ \\
\hline \multirow{4}{*}{$\begin{array}{l}\text { Organic matter } \\
\text { (OM) }\end{array}$} & Shoulder & 30.5 & 29.7 \\
\hline & Chest & 31 & 30.1 \\
\hline & Thighs & 25.5 & 25.6 \\
\hline & Mean & 29 & 28.5 \\
\hline \multirow{4}{*}{ Moisture } & Shoulder & 70.7 & 71.7 \\
\hline & Chest & 71 & 71.5 \\
\hline & Thighs & 71.3 & 71.3 \\
\hline & Mean & 71 & 71.5 \\
\hline \multirow{4}{*}{ Protein } & Shoulder & 19.8 & 20.2 \\
\hline & Chest & 18.7 & 18.9 \\
\hline & Thighs & 20.2 & 21 \\
\hline & Mean & 19.56 & 20.03 \\
\hline \multirow{4}{*}{ Fat } & Shoulder & 6.9 & 5.4 \\
\hline & Chest & 5.8 & 5.2 \\
\hline & Thighs & 6.6 & 4.7 \\
\hline & Mean & 6.4 & 5.1 \\
\hline \multirow{4}{*}{ Carbohydrates } & Shoulder & 1.8 & 2 \\
\hline & Chest & 1.0 & 1.4 \\
\hline & Thighs & 1.8 & 1.9 \\
\hline & Mean & 1.5 & 1.7 \\
\hline \multirow{4}{*}{ Ash } & Shoulder & 1.6 & 1.1 \\
\hline & Chest & 1.4 & 1.7 \\
\hline & Thighs & 2.0 & 1.8 \\
\hline & Mean & 1.6 & 1.5 \\
\hline
\end{tabular}

N.S: Not Significant $(\mathrm{P} \leq 0.05)$.

studied groups were alike to that mentioned early by several investigators such as Grace (1971), Ouhayoun et al. (1981), Altman and Dettmer, (1986), Ouhayoun, (1992), Enser et al. (1996), Pla et al. (1998), Bielanski et al. (2000), Piles et al. (2000), Dalle Zotte (2002), Hu \& Willett, (2002) and Hermida et al. (2006).

Results presented in Table (7) showed that all studied blood constituents in the present study, (Within the normal range according to Nuhu, 2010). Total protein, albumin, globulin, GPT, GOT, creatinine, uric acid, sugar, hemoglobin, red blood cells, white blood cells and platelets, were 
Table 7: Some blood constituents (Within normal range) of NZW rabbits as affected by inclusion dietary moringa leaf meal in their ration (Means $\pm \mathrm{SE}$ ).

\begin{tabular}{|l|c|c|}
\hline \multicolumn{1}{|c|}{ Traits } & $\begin{array}{c}\mathbf{T}_{\mathbf{1}} \\
\text { (0.0 MOLM) } \\
\text { Control }\end{array}$ & $\begin{array}{c}\mathbf{T}_{\mathbf{2}} \\
\text { SBM substitute with (5.2\%) } \\
\text { (MOLM). }\end{array}$ \\
\hline Total Protein( g/dl) & $6.66 \pm .08$ & $6.50 \pm .25$ \\
\hline Albumin (g/dl) & $3.66 \pm .08$ & $3.40 \pm .20$ \\
\hline Globulin (g/dl) & $3.00 \pm .20$ & $3.10 \pm .10$ \\
\hline GPT (U/L) & $73.33 \pm 7.53$ & $79.33 \pm 4.33$ \\
\hline GOT (U/L) & $64.66 \pm 7.44$ & $69.33 \pm 5.23$ \\
\hline Creatinine(MG/DL) & $0.86 \pm .03$ & $0.86 \pm .03$ \\
\hline Uric acid(MG/DL) & $3.76 \pm .63$ & $3.33 \pm .73$ \\
\hline Sugar(MG/DL) & $78.00 \pm 2.51$ & $76.33 \pm .88$ \\
\hline Hemoglobin(g/dl) & $13.16 \pm .66$ & $12.96 \pm .83$ \\
\hline Red Blood Cells(U/L) & $6.55 \pm .26$ & $6.44 \pm .31$ \\
\hline White Blood Cell(U/L) & $7.13 \pm .85$ & $7.96 \pm 1.04$ \\
\hline Platelets(U/L) & $103.33 \pm 8.64$ & $113.00 \pm 7.00$ \\
\hline
\end{tabular}

N.S : Not Significant $(\mathrm{P} \leq 0.05)$.

$\mathrm{SE}=$ standard error

not statistically significant $(\mathrm{P} \leq 0.05)$ by substituent $3.2 \%$ soybean meal with $5.2 \%$ MOLM in treatment group as compared with control group. These results refer that using moringa leaf meal in rabbit diet substitute with a part of soybean meal has no adverse effect on clinical and health status of rabbits since ingestion of dietary components has measurable effect on blood composition (Church et al., 1984).

Madubuike and Ekenyem (2006) indicated that there is evidence in literature that haematological characteristics of livestock suggest their physiological disposition to the plan of nutrition. It may then be suggested that, the different diets imposed on the rabbits were balanced in their formulation to support relatively high performance and maintain the normal haematological profile of the rabbits. The obtained results in the present study was in full agreement with that of each of Nuhu (2010) who found that increasing level of $\operatorname{MOLM}(0,5,10,15$, and 20\%) in the rabbit's feed did not vary the blood characteristics studied. Also, Ewuola et al. (2012) reported that, rabbits fed diets contained 0, 5, 10 and 15\% Moringa oleifera leaf meal (MOLM) showed that all the haematological parameters measured in their experiment were within the normal physiological ranges reported for rabbits most especially haemoglobin, red blood cells, white blood cells, as same as there were no significant differences $(\mathrm{P} \leq 0.05)$ in the mean values of the 
various biochemical components of rabbits studied (total protein, albumin, globulin, urea, creatinine, Cholesterol and Glucose).

Odetola et al. (2012), obtained the same former results dealing with blood constituents, except white blood cells which decreased significantly $(\mathrm{P} \leq 0.05)$ as the inclusion level of Moringa oleifera increased, they attributed the lower value of WBC observed in rabbits fed MOLM based diets compared with the control is an indications that the immunity levels of the rabbits were not challenged. On contrast, Ibrahim et al., (2014) found that red blood cells count, hemoglobin concentration increased $(\mathrm{P}<0.05)$ in the rabbits fed $2 \mathrm{~g}$ (35.77\%) and fed $4 \mathrm{~g}(13.82 \%)$ moringa peregrine seeds (MPS) / kg diet as compared to control group. They attributed that the increase in the hemoglobin concentration of rabbits might be due to the fact that MPS is rich in amino acids, vitamins and minerals particularly iron (Subadra et al., 1997 and Faye et al., 2014). Also, they found that the White blood cells were significantly $(\mathrm{P}<0.05)$ higher in the rabbits supplemented with $4 \mathrm{~g}$ MPS by $42.37 \%$ as compared to the control group. Ibrahim et al., 2014 also found that albumin, glucose, urea concentrations were decreased $(\mathrm{P}<0.05)$ in the rabbits fed $4 \mathrm{~g}$ MPS as compared to rabbits of control group. In the same trend, Said (2014) found that Rabbit fed 3\% MPLM recorded the highest $(\mathrm{P} \leq 0.05)$ urea, total lipid and creatinine values $(53.37,286.8$ and $0.95 \mathrm{mg} / \mathrm{dl})$ compared with control $(44.76,193.8$ and $0.79 \mathrm{mg} / \mathrm{dl})$.

Results of rabbit's economical efficiency as affected by feeding on dietary moringa leaf meal (MOLM) are presented in Table 8.

Table 8: Economical efficiency (\%) for weaned NZW rabbits as affected by feeding on dietary moringa leaf meal. at $13^{\text {th }}$ week of age.

\begin{tabular}{|c|c|c|}
\hline Items & $\begin{array}{c}\mathbf{T}_{\mathbf{1}} \\
(\mathbf{0 . 0} \text { MOLM) } \\
\text { Control }\end{array}$ & $\begin{array}{c}\mathbf{T}_{\mathbf{2}} \\
\text { SBM substitute with } \\
\mathbf{( 5 . 2 \% )}(\mathbf{M O L M})\end{array}$ \\
\hline Price kg per feed (pound) & 2.96 & 2.88 \\
\hline Price kg per meat (pound) & 25 & 25 \\
\hline Feed cost per kg gain & 13.77 & 13.27 \\
\hline Economical efficiency (\%) & 81.47 & 88.28 \\
\hline
\end{tabular}

Results of Table (8) showed that rabbits in treatment Moringa oleifera leave meal (MOLM) had the highest economical efficiency $(88.28 \%)$ than $(81.47 \%)$ for treatment control group, respectively. The obtained results may be due to the insignificant higher body weight gain (5-12 weeks) for Moringa oleifera leave meal MOLM (1136.25g) as compared with (1126.86 g) for 
control, respectively. These results were in full agreement with that of A.Y.El -Badawi et al (2014); Ibrahim et al (2014); Safwat et al (2014) and Said (2014) they reported improvement with inclusion MOLM in rabbit's feed. However, Nuhu (2010) found similar economic efficiency in feed cost per kg weight gain due to the lower feed conversion and higher daily weight gain by increasing MOLM $(0,5,10,15$, and 20\%) in the rabbit's feed.

Conclusively, it can be concluded that, Moringa oleifera Leaf Meal (MOLM) can be used safely in feeding New Zealand White rabbits to alternate a part of rabbit food (Soybean meal) with untraditional food in Egypt such as

MOLM without any adverse effect on the growing, slaughter test, meat quality and blood characteristics, under environmental Egyptian conditions.

\section{REFERENCES:}

Aboh AB, JT Dougnon, IG Tossa, MT Kpodekon, RPA Akakpo, I Youssao (2012). Growth Performance, hematological and serum characteristics of rabbit fed Moringa oleifera Leaves pellets. as substitute to commercial concentrate. Animal Veterinary Science, 2(8),454-458.

Adeniji, A.A. and M. Lawal, (2012). Effects of replacing groundnut cake with Moringa oleifera leaf meal in the diets of grower rabbits. International Journal of Molecular Veterinary Research, 2(3): 8-13.

Adeniji, A.A., E.S. Gana, I.C. Chibuogwu and R.U. Onyia, (2010). The feeding value of Moringa oleifera leaves for growing rabbits, In: Proc. 36 Ann. Conf., Nig. Soc. Animal Production (NSAP), March 13-16, 2011, University of Abuja, Nigeria, pp: 610-613.

Altmann P. L., Dettmer D. (1986). Metabolism. In: Fed. of Am. Soc. for Exper. Biol. Bethesda, Maryland, $737 \mathrm{pp}$.

A.O.A.C. (1994). Official Methods Of Analysis. (15 ${ }^{\text {th }}$ Ed.) Washington, DC: Association of Official Analytical Chemists.

Ayssiwede SB., Zanmenou JC., Issa Y., Hane MB., Dieng A., Chrysostom CAAM., Houinato MR., Hornick JL., Missohou A. (2011): Nutrient composition of some unconventional and local feed resources available in Senegal and recoverable in indigenous chickens or animal feeding. Pak. Journal of Nutrition Davoust C, 2011; 10: 707-717.

Bielanski P., Zajac J., Fijal J. (2000): Effect of genetic variation of growth rate and meat quality in rabbits, In: Proceedings of the 7th World Rabbit Congress, July 4-7, Valencia, Spain: 561-566. 
Blasco, A.; J., Ouhayoun and G. Masoero (1993). Study of rabbit meat and carcass criteria and terminology. 2nd Conference on Rabbit Production and Genetics. In The Mediterranean Area, 3-7 September, Zagazig, Egypt.

Cheeke, P.R. (1987). Rabbit Feeding and Nutrition. Academic Press, Orlando, Florida USA. 376p.

Church, JP, Jude, JJ, Young, CW, Kebay JI and Kim, WW. (1984). Effects of Moringa Oleifera Leaves on Hematological Indices in Humans. American Journal of clinical Nutrition, 40:1338-1344.

Dalle Zotte A. (2002). Perception of rabbit meat quality and major factors influencing the rabbit carcass and meat quality. Livest. Prod. Sci., 75: 1132.

Davice, J. U., and Lewis, S. M. (1991). Practicalhematology, $8^{\text {th }}$ Edition. Longman Ltd., London, U.K., pp 22-28.

Dougnon T. J., Aboh B. A., Kpodékon T. M., Honvou S. Youssao I. (2012). Effects of substitution of pellet of Moringa oleifera to commercial feed on rabbit's digestion, growth performance and carcass trait. Journal of Applied Pharmaceutical Science, Vol. 2 (9), pp. 015-019, September, 2012

Duncan, D.B., 1955. Multiple Rang and Multiple F-Test. Biometrics, 11:1-42.

Duke,A.O.,Dim,N.I.,Aganga,A.A.(1998).NoteonComparativeEvaluationofPalm Kernel Meal, Peanut Meal and Sun Flower Meal in Diets for Weanling Rabbits. J. Appli. Rabbit Res., 11 (5):264 - 265.

El-Badawi, A.Y., H.A.A. Omer, A.A. Abedo and M.H.M. Yacout (2014). Response of Growing New Zealand White Rabbits to Rations Supplemented with Different Levels of Moringa oleifera Dry Leaves Animal Production Department, National Research Centre, Dokki, Giza, Egypt2 By-Product Utilization Department, Institute of Animal Production, Agriculture Research Centre, Dokki, Giza, Egypt .

Enser M., Hallet K., Hewitt B., Fursey G. A. J., Wood J. D. (1996). Fatty acid content and composition of English beef, lamb and pork at retail. Meat Sci., 42(4), 443-456.

Ewuola, E.O., O.A. Jimoh, O.V. Atuma and O.D. Soipe, (2012). Haematological and serum biochemical response of growing rabbits fed graded levels of Moringa oleifera leaf meal. Proceedings of $10^{\text {th }}$ World Rabbit Congress, Sharm El-Sheikh, Egypt, pp: 679-683.

Faye, B., Bucheton, B. and Banuls, A.L. (2014). Prevalence of leishmania infantum in a rural area of Senegal: analysis of risk factors involved in transmission to humans. J. Trans. R. Sco Trop Med Hyg., 105: 333- 340. 
Grace, R.I. (1971). The significance of meat for nutrition. Food Science and Technology Abstracts, 8:131-138.

Guèye, E.F. and Branckaert, R.D.S.(2002).FAO' sprogramme for support to family poultry production. Proceedings of a workshop on poultry as a tool in poverty eradication and promotion of gendered quality. Animal Production and Health Division, FAO, Rome, Italy.

Hermida M., Gonzalez M., Miranda M., Rodriguez- Otero J.L. (2006): Mineral analysis in rabbit meat from Galicia (NW Spain). Meat Science, 73: 635-639.

Hu F.B., Willett W.C. (2002): Optimal diets for prevention of coronary heart disease. Journal of the American Medical Association, 288: 2569-2578.

Ibrahim, N.H.; Morsy, A.S. and Ashgan, M.E. (2014). Effect of Moringa Peregrine Seeds on Productive Performance and Hemato-Biochemical Parameters of growing rabbits. Journal of American Science,10(6) pp 7-12.

Kpodékon M., Youssao AKI., Koutinhouin GB., Baba IL., Dessou JM., Djago Y. (2009): Effet de la granulation sur les performances de croissance, l'efficacité alimentaire et la viabilité des lapereaux en condition d'élevage tropical. Revue Élev. Méd. vét. Pays trop., 62 (1): $75-80$.

Madubike, F.N. and Ekenyem, B.U. (2006).Hematology and Serum Biochemistry Characteristics of Broiler Chicks fed varying Dietary Levels of Ipomoea Asarifolia leaf meal. Int. J. Poultry. Sci., 5:9-12.

Mutayoba SK., Dierenfeld E., Mercedes VA., Frances Y., Knight C.D. (2011): Determination of chemical composition and ant-nutritive components for Tanzanian locally available poultry feed ingredients. International Journal of Poultry Sci., 10: 350-357.

NRC (1977). National Research Council. Nutrient Requirements of Rabbits. $2^{\text {nd }}$ Rev. ed. National Academy of Sciences, Washington. D.C., USA.

Nuhu F. (2010): Effect of Moringa oleifera Leaf Meal (MOLM) on Nutrient Digestibility, Growth, Carcass and Blood Indices of Weaned Rabbits. A Thesis Submitted to the School of Graduate Studies, Kwame Nkrumah University of Science \& Technology, Kumasi, Ghana. In partial fulfillment of the Requirements for the Award of MS Degree in Animal Nutrition, 90 pp.

Odetola, O.M., Adetola, O.O., Ijadunola, T.I., Adedeji, O.Y and Adu, O.A (2012): Utilization of moringa (Moringa oleifera) leaves meal as a replacement for soya bean meal in rabbit's diets. Scholarly Journal of Agricultural Science, 2 (12):309-313. 
Ouhayoun J. (1992). Rabbit meat, Characteristics and qualitative variability. Cuni Sciences, 7(1): 1-15.

Ouhayoun J., Demarne Y., Lebas F. (1981). Use of rapeseed in the growing rabbit diet. Effect on carcass quality. Ann. Zootech., 30, 325-333.

Oyedele O.J., Odeyinka S.M., Adeleke T.O., Odedire J.A. (2008). Reproductive performance of rabbits fed Moringa oleifera as a replacement for centrosema pubescens, 9th World Rabbit Congress, Verona, Italy, 411-415.

Peters, T., Biomonte, C.T., and Doumas, B.T. (1982). Protein (total protein) in serum, urine and cerebrospinal fluid, albumin in serum. In selected Methods Of Clinical Chemistry, Volume 9, 1982.

Piles M., Blasco A., Pla M. (2000). The effect of selection for growth rate on carcass composition and meat characteristics of rabbits. Meat Science, 54: 347-355.

Pla M., Guerrero L., Guardia D., Oliver M. A., Blasco A. (1998). Carcass characteristics and meat quality of rabbit lines selected for different objectives: Between lines comparison. Livest. Prod. Sci., 54, 115-123.

Reitman S \& Frankel S. (1957). A colorimetric method for the determination of serum glutamic oxalacetic and glutamic pyruvic transaminases. Amer. J. Clin. Pathol., 28: 56-63.

Safwat M. L., Sarmiento-Franco, R. H. Santos-Ricalde D. Nieves and C. A. Sandoval-Castro (2014).Estimating Apparent Nutrient Digestibility of Diets Containing Leucaena leucocephala or Moringa oleifera Leaf Meals for Growing Rabbits by Two Methods. Asian Austral. J. Anim. Sci., 28 (8): 1155-1162.

Said E.M. El-Sheikh (2014). The influence of moringa peregrine leaves as a feed supplement on growth performance, digestibility, blood characteristics and carcass traits of growing rabbits. The International Conference on Rabbit Production in Hot Climate, 8-12 September, 2014, 347- 361.

Sarwatt, S. V. ; Kapange, S. S. ; Kakengi, A. M. V.(2002). Substituting sunflower seed-cake with Moringa oleifera leaves as a supplemental goat feed in Tanzania. Agro forestry Systems, 56 (3): 241-247.

Snedecore, G.W. and W.G. Cochran, 1984. Statistical Methods. $6^{\text {th }}$ ed. Iowa State University Press. Ames, Lowa, U.S.A.

SPSS (2004). Statistical Package for Social Sciences, Chicago, U.S.A.

Subadra, S., Monica, J. And Dhabhai, D. (1997).Retention and storage stability of beta-carotene in dehydrated moringa oleifera. Inter. Journal of Food Science and Nutrition, 48:373 - 379. 
Ufele, A. N., Ebenebe, C. I., Igwe, I. I., Mogbo, T. C., Akunne, E. C. And Aziagba, B. O. (2013). The Effects of Drumstick Tree (Moringa oleifera) Leaf Meal on the Average Weight Gain of Domestic Rabbits (Oryctolagus cuniculus). The Bioscientist, 1(1):106-108.

\section{تأثير استخدام أوراق المورينجا في عليقة أرانب التيوزيلتدى النامية على التى

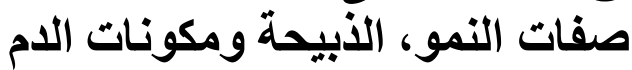

\section{احمد عبدالوهاب جمعةـ على عبد العظيم رشوان- مصطقى ابراهيم توفيق}

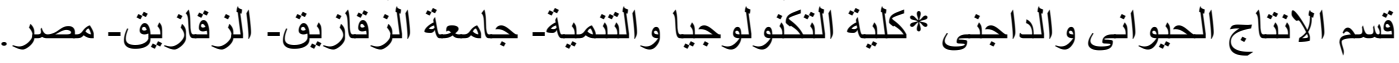

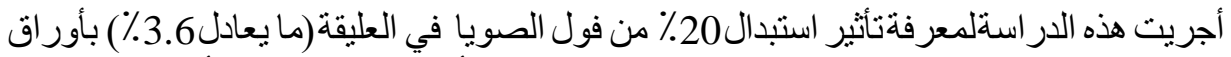

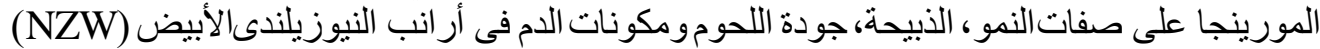

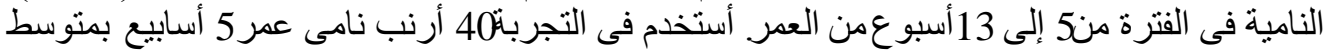

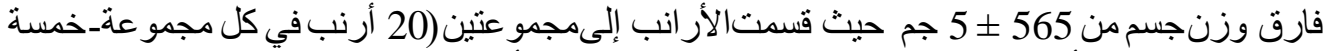

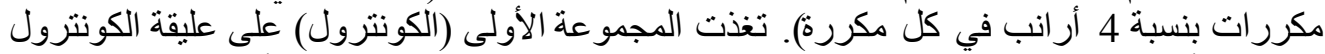

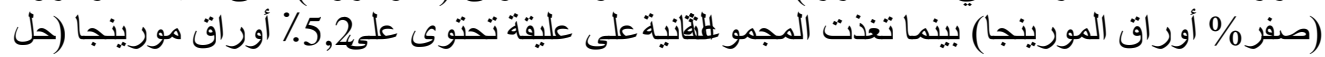

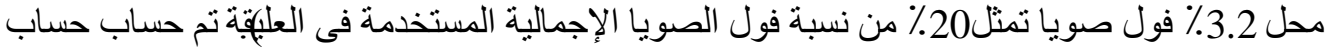

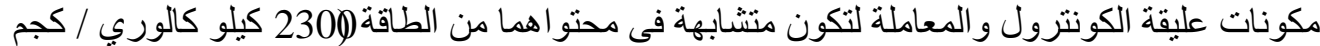

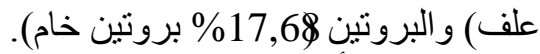

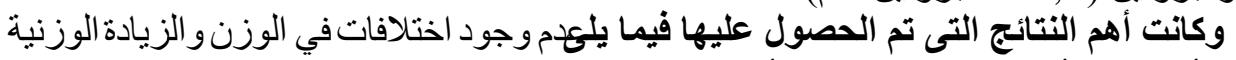

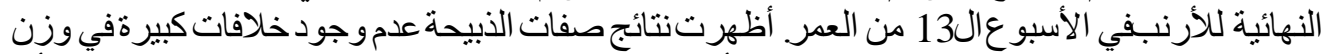

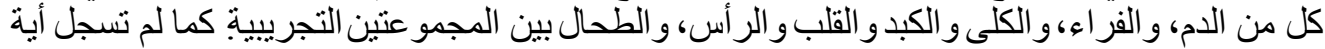

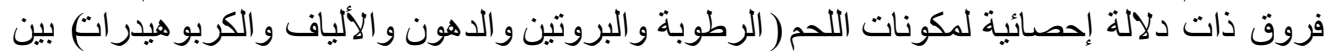

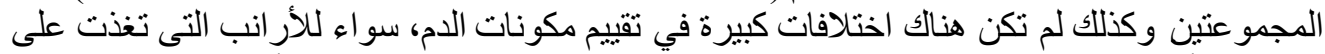

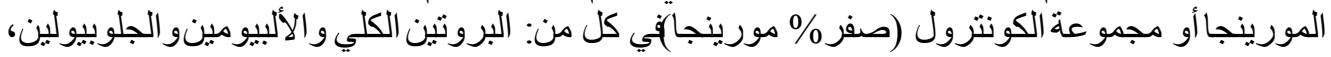

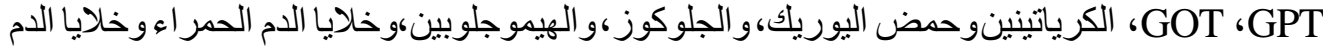

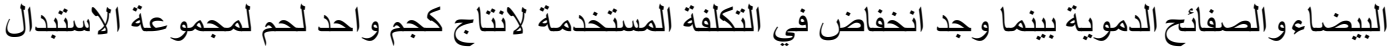

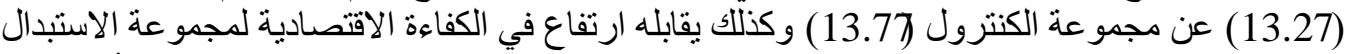

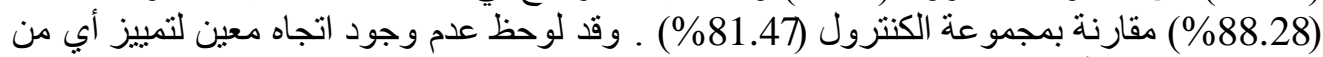
المجمو عتينعن الأخرى

التوصية: بناء على النتائج يمكن استنتاج أن مسحوق أور اق نبات المبات المورينجا يمكن استخدامها

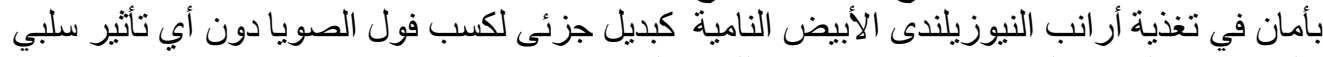

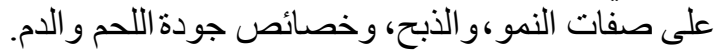

